\title{
Modi memorandi. Pamiętanie i przeżywanie Wielkiej Wojny wtedy i dzisiaj. Próba komparatystyczna*
}

DOI: http://dx.doi.org/10.12775/LC.2018.029

\begin{abstract}
Streszczenie: Artykuł jest próbą zarysowania sposobów upamiętniania I wojny światowej, jakie zostały wypracowane po jej zakończeniu w obrębie sztuk wizualnych w Wielkiej Brytanii i Polsce. Autor zestawia ówczesne formy upamiętniania ze współczesnymi sposobami pamiętania wojny przez artystów. Przedmiotem analizy są zwłaszcza performatywnie rozumiane wystawy sztuki wojennej organizowane w obu krajach jeszcze w trakcie trwania wojny oraz realizacje artystów współczesnych w różny sposób będące dziełami sztuki o charakterze performatywnym i partycypacyjnym.
\end{abstract}

Słowa kluczowe: I wojna światowa, pamięć wizualna wojny, performatywność, wystawy sztuki wojennej, sztuka współczesna o Wielkiej Wojnie, komparatystyka

Historyk i krytyk sztuki oraz kurator wystaw sztuki współczesnej; adiunkt w Instytucie Historii Sztuki Uniwersytetu Warszawskiego. E-mail:wj.szymanski@uw.edu.pl.

" Badania zostały sfinansowane ze środków Narodowego Centrum Nauki, przyznanych w ramach finansowania stażu po uzyskaniu stopnia naukowego doktora na podstawie decyzji numer DEC-2014/12/S/HS2/00385. 


\title{
Modi memorandi. Re-membering and Re-living the Great War in the Past and in the Present: A Comparative Approach
}

\begin{abstract}
The present paper is an attempt to provide an overview of a number of ways in which the Great War has been remembered. Special attention will be paid to Polish and British visual arts and their responses to the memory of the Great War. The paper juxtaposes the past forms of commemorating the Great War with the present-day modes of remembering it. What the paper is particularly interested in is the performative potential of the Great War exhibitions organised in both countries already during the war, as well as contemporary works of art which are both performative and participatory.
\end{abstract}

Keywords: First World War, visual memory of the Great War, performativity, the Great War art exhibitions, contemporary art on the Great War, comparative studies

Lire c'est re-lire.

Georges Poulet

ez wątpienia I wojna światowa wytworzyła w biorących w niej udział społeczeństwach pilną potrzebę właściwego jej upamiętnienia. Potrzeba ta była na tyle nagła, że jeszcze w trakcie działań wojennych zostały podjęte istotne próby o charakterze komemoratywnym, w różnoraki sposób konceptualizujące Wielką Wojnę i usiłujące ująć ją jako dyskursywne miejsce pamięci. Działania zmierzające do zrozumienia wojny jako miejsca pamięci były prowadzone w pierwszej kolejności pod auspicjami państw biorących udział w konflikcie, jak również społeczności lokalnych pośrednio lub bezpośrednio dotkniętych działaniami wojennymi, konkretnych instytucji i towarzystw włączających się w dzieło upamiętnienia oraz, co zrozumiałe, milionów rodzin i osób prywatnych, które na frontach wojennych straciły swoich bliskich.

Ów nagły i potężny wybuch potrzeby pamiętania właściwie od samego początku był ściśle związany z problemem natury etycznej i estetycznej zarazem, ze wspomnianą właśnie i zasadniczą kwestią właściwego, tj. odpowiedniego upamiętnienia. Etyczno-estetyczne debaty na temat tego, w jaki sposób dobrze i godnie pamiętać, rozgorzały niemal na całym świecie biorącym udział w wojnie jeszcze w trakcie jej trwania lub bezpośrednio po jej zakończeniu ${ }^{1}$. Ich nagłość oraz mnogość pomysłów na właściwe upamiętnienie zdumiewa nawet po stu latach, jakie minęly od zakończenia konfliktu, i jednocześnie wskazuje na lata 1914-1918 jako na czas niezwykłych przemian w świadomości indywidualnej oraz kolektywnej. Wojny przecież prowadziła ludzkość od swojego zarania; historia tradycji ich upa-

1 Świetnie tę sprawę na gruncie brytyjskim, na przykładzie sporów o cmentarze wojenne i ich formy analizuje David Crane (2013: 138-165). 
miętniania jest równie stara i można $\mathrm{z}$ łatwością prześledzić ją przynajmniej od starożytności. Jak to się stało, że zaledwie pięć lat po tym, gdy w 1913 roku niemalże cała Europa oddawała się hucznym ceremoniom pamięci związanym ze stuleciem kolektywnego pokonania Napoleona Bonapartego pod Lipskiem, uznano, że wypracowane w przededniu Wielkiej Wojny sposoby komemoracji są przynajmniej nieadekwatne, proponując w zamian cały nowy arsenał strategii pamięciowych i wytwarzając nowy kulturowy krajobraz pamięci?

Trzeba tutaj podkreślić, że I wojna światowa, biorąc pod uwagę jej skalę - zasięg terytorialny, liczbę osób biorących w niej udzial, jak również ofiar, które pochłonęła, oraz użycie i rozwój nowych broni i taktyki wojennej - istotnie była wydarzeniem bez precedensu w historii konfliktów zbrojnych. To zaś powodowało ogólną konfuzję przy próbach zrozumiałego opowiedzenia jej przebiegu oraz ujęcia w sensowną narrację. Ta swego rodzaju nienaturalność, mówiąc słowami Haydena White’a (2009: 308), czy też niesamowitość, używając kategorii z zakresu psychoanalizy freudowskiej, wydarzenia, jakim była wojna, powodowała rozmaite problemy natury etycznej i estetycznej, które możemy wyrazić za pomocą motta: „stosowność a forma”. Kłopotano się więc z doborem słów w literaturze o charakterze świadectwa, próbując zdać relację z czegoś, co było przecież według licznych świadków nie do opowiedzenia ${ }^{3}$, szukano właściwych figur retorycznych, stylistycznych i kompozycyjnych w sztukach wizualnych, usiłując uchwycić istotę wojny, której sens wymykał się jednak tradycyjnej reprezentacji ${ }^{4}$. Chociaż w obiegu wystawienniczym wciąż była tradycyjna estetyka batalistyczna wypracowana przez akademizm XIX stulecia ${ }^{5}$, w obliczu takiego kryzysu reprezentacji sięgano coraz chętniej po nowoczesne środki wyrazu, „odkryte" przez awangardę europejską w latach poprzedzających wybuch wojny. W 1938 roku Gertruda Stein pisała:

Kompozycja wojny 1914-1918 różniła się od kompozycji poprzedzających ją wojen, ponieważ nie układała się dokoła jednego człowieka, stojącego w środku i otoczonego gromadą innych ludzi, była inna, bez początku i końca, każdy róg był równie ważny - innymi słowy, była to kompozycja kubistyczna (Stein 1974: 26-27).

Owo, zauważane już niejednokrotnie, wspólistnienie estetyk, tradycyjnej oraz nowoczesnej, jest niezwykle ciekawym, ale tylko jednym z wielu aspektów pamięciowego boomu wojny (Winter 2014: 2-5). Tym jednak, co najbardziej interesujące z punktu widzenia powojennych praktyk pamięciowych, było - odróżniające ten konflikt od jakiegokolwiek wcześniejszego - powstanie całego zasobu form składających się na, jak je określa Jay Winter, kulturowe kody języków żałoby (ibid.: 5-7). Te języki żałoby zdominowały powo-

\footnotetext{
2 Odwołuję się do tytułu książki pod redakcją Michała Głowińskiego Stosowność i forma. Jak opowiadać o Zagładzie?, której pierwsza część tytułu doskonale oddaje poruszany tutaj problem natury etyczno-estetycznej.

3 "Brakowało słów i metafor do opisania owego nieoczekiwanego doświadczenia”, pisał Modris Eksteins, analizując liczne świadectwa pisemne żołnierzy (Eksteins 2014: 320).

4 "To jest nie do wypowiedzenia", pisał w liście do żony Paul Nash (1949: 211). O ile nie zaznaczono inaczej, przekłady na język polski pochodzą od autora artykułu.

${ }^{5}$ Formuły malarstwa akademickiego były równoległe do tendencji nowoczesnych. Często faworyzowano artystów akademików, a ich prace trafiały na pocztówki, ilustrowane materiały propagandowe, do prasy w całym ogarniętym wojną świecie. Przykładem akademizmu może być weteran kolonialnego malarstwa batalistycznego, malarz wojen burskich, William Barnes Wollen, a także starszy od niego o rok Wojciech Kossak.
} 
jenny krajobraz pamięci w wielu krajach upamiętniających wojnę. Żałoba, utrata, zaduma nad przerwanym życiem stały się właściwym sposobem pamiętania nawet w krajach zwycięskich, odsuwając na bok narracje i wizualizacje podkreślające triumfalizm, radość z drogo okupionego zwycięstwa, postawę afirmatywną. Naturalnie podkreślano wciąż męstwo i bohaterstwo żołnierzy, znaczenie ich ofiary, patriotyzm postawy; taka retoryka jednak nie była w narracji o wojnie dominująca, ustępowała miejsca nowoczesnej pamięci wojennej ogniskującej się raczej na upamiętnieniu poległych niż na manifestowaniu doraźnych racji politycznych.

Ów język żałoby wpłynął właśnie na to, że pamiętanie stało się częścią (nie tylko) europejskiego krajobrazu. „Każdy, kto przemierza północną Francję lub Flandrię, odnajdzie ślady okropnych, wręcz niewyobrażalnych ludzkich strat wojny i prób upamiętnienia poległych", pisał z brytyjskiej perspektywy Winter (ibid.: 1). Ale to samo przecież można powiedzieć o wielu innych regionach Europy ${ }^{6}$, której ratusze, kościoły parafialne, siedziby uniwersytetów, banków i towarzystw ubezpieczeniowych, a także dworce kolejowe zostały dosłownie obwieszone tablicami upamiętniającymi poległych, zaś rynki i place miast oraz miasteczek zabudowane pomnikami wojennymi, krzyżami pamięci i obeliskami, pola bitewne natomiast i dawne tereny teatru wojny pokryte starannie zaprojektowanymi i po raz pierwszy budowanymi na taką skalę i z taką determinacją cmentarzami wojennymi ${ }^{7}$. Nowością były wznoszone ze środków publicznych upamiętniające bitwy i poległych, $\mathrm{w}$ tym niezidentyfikowanych i nieodnalezionych, memoriały na polach bitew, groby nieznanych żołnierzy powstające w latach dwudziestych, a także cenotafy, których długa tradycja została po 1918 roku odświeżona i ponownie uruchomiona w celu wytwarzania wojny - miejsca pamięci ${ }^{8}$.

Co pozostało dzisiaj po zarysowanej powyżej kulturze pamięci wojny, kiedy nie ma już ludzi, którzy bezpośrednio pamiętają Wielką Wojnę i którzy byli jej uczestnikami oraz świadkami - ludzi, na potrzeby których stworzono pamięć wojny? W jaki sposób Wielka Wojna jest pamiętana dzisiaj, w czasach, w których po niewyobrażalnych dla ludzi w 1918 roku okropieństwach kolejnych wojen i ludobójstwach XX i XXI wieku, trzeba nam pamiętać coraz więcej ofiar? Jak funkcjonuje postpamięć Wielkiej Wojny?

Frapujące jest pewne podobieństwo świata sprzed stu lat i nam współczesnego. Żyjemy bowiem w czasach opętanych wręcz potrzebą pamiętania; w czasach, pośrednim dowodem może być także ten tekst, które coraz częściej odchodzą od tradycyjnego rozumienia historii, skupiając się na studiach nad pamięcią właśnie; „Imperatywem naszej epoki jest utrzymanie wszystkiego i zachowanie każdej oznaki pamięci”, wskazuje klasyk studiów nad pamięcią, Pierre Nora (1989: 14). Zaś w ujęciu Sharon Macdonald:

Europa stała się krainą pamięci owładniętą obsesją znikania pamięci zbiorowej i jej prezerwacją. Krajobraz Europy i jej miast jest wypełniony produktami pracy pamięci zbiorowej: obiektami dziedzictwa, memoriałami, muzeami, tablicami i instalacjami sztuki zaprojektowanymi,

\footnotetext{
${ }^{6}$ By przywołać w tym miejscu tereny Beskidów zabudowane przez Austriaków ponad trzystoma cmentarzami wojennymi czy nasycone architekturą sepulkralną pogranicze włosko-austriackie i włosko-słoweńskie.

7 Cmentarze wojenne tworzone na polach bitew budowano jeszcze w XIX wieku. Dla nekropolii Wielkiej Wojny istotne wydają się zwłaszcza cmentarze z okresu wojny secesyjnej (1861-1865) oraz wojny krymskiej (1853-1856).

8 Więcej na temat historii memoriałów, cenotafów i grobów nieznanego żołnierza pisałem przy okazji analizy znaczeń mauzoleum Paula von Hindenburga (Szymański 2015a).
} 
aby przypominać nam historie, które mogłyby zostać w innym razie utracone. Coraz więcej ludzi żyje i pracuje w miejscach pamięci, a także je odwiedza [... ]. Lokalne towarzystwa miłośników historii, grupy rekonstrukcyjne i prowadzone przez wolontariuszy projekty dotyczące dziedzictwa kwitną. Książki z wyimkami z przeszłości i sepiowymi fotografiami miejscowości i społeczności zapełniają pułki bibliotek i księgarni. Jak również książki o naszej fiksacji na temat pamiętania oraz przeszłości (Macdonald 2013: 1).

W dalszej części artykułu chciałbym zastanowić się, jakie miejsce zajmowała wówczas, a jakie zajmuje dziś w tym pejzażu pamięci i społeczeństwach owładniętych pamiętaniem pamięć Wielkiej Wojny. Z racji tego, że tak wówczas, jak dziś artystki i artyści odegrali i odgrywają znaczącą rolę w konstruowaniu pamięci oraz postpamięci I wojny światowej, będą mnie interesowały realizacje artystyczne (wizualne). Takie, które wytworzyły znaczenia wojny po wojnie, i takie, które - posługując się słowami Marii Janion ${ }^{9}$ - odnawiają te znaczenia dzisiaj. Pole swoich rozważań ograniczę zaś do porównania pejzaży pamięci pierwszowojennej w dwóch krajach - Polsce oraz Wielkiej Brytanii.

\section{(1) Pamięć wojny po wojnie. Jak się wystawia historię?}

Rozpatrując udział polskich i brytyjskich artystów sztuk wizualnych w działaniach wojennych, należy na samym początku wyjaśnić pozycje, z których oglądali oni, przeżywali i przedstawiali fronty Wielkiej Wojny. Z jednej strony mamy zatem do czynienia z twórcami, którzy na wojnie znaleźli się jako w pierwszej kolejności żołnierze, rekruci lub ochotnicy. Z takiej, żołnierskiej właśnie, perspektywy wojnę w początkowej jej fazie widzieli np. C. R. W. Nevinson i Eric Kennington ${ }^{10}$, a także Polacy w armii austriackiej - sędziwy Wojciech Kossak oraz rosyjskiej - Władysław Strzemiński i Witkacy, jak również niemal dwustu artystów, którzy znaleźli się po drugiej stronie frontu - w sformowanych pod auspicjami austriackimi Legionach Polskich ${ }^{11}$. Z drugiej zaś strony znamy nazwiska artystów zatrudnionych przez rządy państw biorących udział w wojnie i powołanych do służby jako oficjalni i opłacani artyści wojenni. Można wymienić np. takich zatrudnionych przez brytyjskie Ministerstwo Informacji artystów wojennych, jak: Muirhead Bone, Paul Nash, Percy Wyndham Lewis, David Bomberg (Gough) oraz Polaków pracujących w Kunstgruppach armii austriackiej: Alfonsa Karpińskiego, Fryderyka Pautscha, Henryka Uziembłę. Osobną grupę stanowili żołnierze, którzy mimo iż nie byli artystami profesjonalnymi, pozostawili po sobie świadectwa wizualne - niedoceniane zazwyczaj wówczas, na światło dzienne

9 Odwołuję się tutaj do tytułu książki Marii Janion pt. Odnawianie znaczeń.

10 Artysta zaciągnął się do wojska jako kierowca ambulansu Czerwonego Krzyża w 1914 roku. Służył w tej funkcji na froncie zachodnim do urlopowania w 1916 roku. Od 1917 wrócił na front jako oficjalny artysta wojenny. Kennington natomiast walczył od 1914 do czerwca kolejnego roku, kiedy to z powodu ran odesłano go do domu. Jako oficjalny artysta wojenny przebywał we Francji od 1917 roku (Art from the First World War 2014: 14, 54).

11 Najpełniejszą listę nazwisk, w tym Tadeusza Ajdukiewicza, Leona Chwistka i Edwarda Rydza „Śmigłego”, podają Wacława Milewska i Maria Zientara (1999: 94-105). 
wychodzące często po latach, ale niezwykle cenne z perspektywy czasu - rysunki, zdjęcia i szkice. Z punktu widzenia zaś interesującej mnie tutaj problematyki związanej z wytwarzaniem wizualnej pamięci wojny, nie można nie wspomnieć o jeszcze jednym, osobnym gatunku twórców (i twórczyń). Mam na myśli takich artystów, w których pracach pojawiają się przedstawienia wojny lub występuje ona w nich w sposób alegoryczny lub pośredni (jak w portretach mężczyzn w mundurach wojskowych), ale którzy nigdy nie doświadczyli i nie zobaczyli na własne oczy frontu. To np. wspomniany już William Barnes Wollen, który malował Wielką Wojnę z oddali, ale nigdy nie oglądał jej osobiście, podobnie zresztą jak konfliktów kolonialnych zajmujących go w XIX wieku. W malarstwie polskim takim przykładem może być Jacek Malczewski, w którego pracach pojawiają się tematy wojenne i który stworzył emblematyczne dla kultury polskiej przedstawienia, takie jak Dwa pokolenia (1915) czy Nike Legionów (1916), całą wojnę spędzając w Krakowie i Wiedniu.

Drugim, niezwykle istotnym i zasadniczym z mojego punktu widzenia zagadnieniem, jakie pojawia się przy próbie rozpoznania zależności między sztuką wojenną z okresu I wojny światowej a wytworzeniem za jej pomocą określonych sposobów pamięci wizualnej i przeżywania wojny, jest instytucjonalizacja tej sztuki. Proces ten nie polega bowiem tylko na stworzeniu ram funkcjonalnych dla twórczości artystycznej czasu wojny, lecz - przede wszystkim - na wytwarzaniu sposobów pamiętania właśnie. Jest to proces o kapitalnym znaczeniu, który za pomocą takich wydarzeń, jak medium wystawy, użycie graficznej i fotograficznej reprodukcji form i znaczeń oraz ich dyskursywnej obróbki, w performatywny sposób zmienia wojenne artefakty (obrazy, rzeźby, rysunki) w choreograficzne instrukcje dla ruchu myśli, jaki każdorazowo zachodzi w procesie pamiętania i przypominania. Użyte konsekwentnie i powtarzane formy instytucjonalizacji stają się rodzajem skryptu pamięci i przedstawieniem pewnej wersji historii wojennej. Ich kolejne odsłony można więc odczytywać jako - używając terminu Freddiego Rokema - „wystawianie historii” (Rokem 2010: 24); z jednej strony same wystawiają historię, tworząc jej kolejną wersję - reperformują przeszłość historyczną (jej konkretną wizję) i uczą niejako sposobów jej właściwego rozumienia i odczytywania.

Zarówno w Wielkiej Brytanii, jak i w Polsce choreograficzno-sceniczna machina pamięci wizualnej została wprawiona w ruch jeszcze w czasie trwania wojny. Rok po tym, jak wysłano na fronty oficjalnych artystów wojennych, utworzono w 1917 roku w Londynie Imperial War Museum, którego zadaniem była nie tylko opieka nad dziełami sztuki stworzonymi przez artystów opłacanych przez Ministerstwo Informacji. Muzeum bowiem zatrudniło własnych artystów w celu tworzenia wizualnych świadectw konfliktu (Malvern). W 1916 roku Brytyjskie Biuro Propagandy Wojennej rozpoczęło wydawanie periodyku pod znaczącym tytułem „British Artists at the Front”, którego przygotowanie powierzyło artystom młodszej generacji (ibid. $)^{12}$. Na łamach tego czasopisma reprodukowano bezkompromisowe, pozbawione heroizmu i nowoczesne obrazy wojny, które wkrótce stały się emblematyczne dla brytyjskiej pamięci wojennej. Cały numer poświęcono więc wizyjnym, księżycowym, surrealistycznym wręcz pejzażom frontu zachodniego autorstwa Nasha, ko-

\footnotetext{
12 Nie było to, trzeba dodać, jedyne pismo ilustrowane poświęcone wojnie. Przed tym, jak zaczęło się ukazywać, wydawano jeszcze "The Western Front". Obrazy z wojny docierały za linie frontu także za pośrednictwem wypełnionego przede wszystkim starannie selekcjonowanymi fotografiami magazynu „The War Pictorial”.
} 
lejny bezkompromisowo realistycznym i naturalistycznym portretom Kenningtona, a jeden ekspresyjnym i ekspresjonistycznym niemalże świadectwom frontowym Nevinsona.

Natychmiastowa kanonizacja artystycznych wizji wymienionych malarzy, do której doszło za pomocą instytucjonalnych procesów muzealizacji obiektu i redystrybucji jego wizerunku, wspomaganej dodatkowo przez organizowanie indywidualnych lub grupowych wystaw czasowych, ukształtowała - nowoczesną przeważnie - formę wizualnej reprezentacji wojny w kulturze brytyjskiej. Biorąc zaś pod uwagę także kontekst planów wielkich upamiętnień architektonicznych, jakie opracowywano pod koniec wojny i po jej zakończeniu, dostajemy ogólną atmosferę narodzin, interesującego Wintera, narodowego kodu języka żałoby, który bardzo szybko stał się oficjalną wersją historii wojny, będąc gotowym na kolejne wystawienia performansem jej obrazu.

Zadziwiające, jak skutecznie oficjalną pamięć wojny wytworzyła także - pozbawiona porównywalnego chociaż do brytyjskiego zaplecza instytucjonalnego - kultura polska. Pamięć ta i jej jeszcze w czasie wojny wypracowane formy okazały się przy tym na tyle silne, że ich kolejne wersje można obserwować i dziś. Siła tej pamięci została okupiona jednak wielką ofiarą. Ale po kolei.

Chociaż w czasie trwania I wojny światowej nie istniało ani polskie ministerstwo informacji, ani potężne i niezależne biuro propagandy wojennej, w nieistniejącym państwie błyskawicznie i sprawnie zorganizowano instytucjonalną maszynę pamięci, nie mniej efektywną od brytyjskiej. Stało się to za sprawą powstałego w sierpniu 1914 roku w Krakowie proaustriackiego Naczelnego Komitetu Narodowego ${ }^{13}$. To dzięki jego działalności, w szczególności zaś postawie Jerzego Mycielskiego i Jana Bołoza-Antoniewicza, jeszcze w 1915 roku doszło do pierwszych wystaw sztuki legionowej (Milewska i Zientara 1999: 344-346). Wystawy te były prezentowane za granicą (w 1915 roku dwukrotnie w Wiedniu i raz w Baden, w 1917 roku w Szwecji i Szwajcarii), jak również na ówczesnych ziemiach polskich, w Galicji oraz w wyzwalanej od Rosjan Kongresówce. Pierwszą monumentalną wystawą, na której zgromadzono ponad pięćset obiektów, była odbywająca się w marcu i kwietniu 1916 roku w krakowskim Pałacu Sztuki ekspozycja Legiony Polskie, kolejne odbyły się w 1917 roku w warszawskiej Zachęcie, w salach resursy kupieckiej w Lublinie oraz lwowskim Towarzystwie Przyjaciół Sztuk Pięknych (ibid.: 349-354). Jak piszą Wacława Milewska i Maria Zientara, na wystawie w Krakowie „pokazano zarówno prace artystów-żołnierzy powstałe na froncie, jak i dzieła o tematyce legionowej tworzone na głębokich tyłach, w zaciszu pracowni” (ibid.: 349). Co jednak bardziej istotne dla obiegu obrazów i znaczeń oraz siły i zasięgu ich oddziaływania, wystawy uruchomily kolejne mechanizmy ich cyrkulacji:

O zapotrzebowaniu na tego rodzaju sztukę świadczy ogromne powodzenie aukcji i wyprzedaży dzieł sztuki legionowej, a także popyt na reprodukcje wydawane w formie pocztówek zarówno przez Centralne Biuro Wydawnictw NKN, jak i przez różne organizacje społeczne i prywatnych nakładców (ibid.: 346-347).

Tego typu instytucjonalizacja polskiej sztuki wojennej, w której całość przeżywania wojny została zastąpiona doświadczeniem konkretnym, legionowym, przy braku wykształ-

13 Na temat działalności NKN-u szczegółowo pisze Mateusz Drozdowski (2017). 
conych mechanizmów dystrybucji i redystrybucji narracji innych niż legionowa, ukształtowała charakterystyczną i specyficzną - hegemoniczną i właściwie jedyną - oficjalną pamięć wojny. I chociaż figury tej pamięci pozostawiają wiele do życzenia, będąc w ogromnej większości tradycyjnymi obrazami wypracowanymi na wzorcach dziewiętnastowiecznych, w których przeważają konwencjonalne portrety i scenki rodzajowe, kultywujące rodzaj „ułańskiego westernu” (Janion 1998: 36-43), czy ukazujące ów „romantyczno-ułański mit radości” (Traba 2003: 64), są z punktu widzenia performatywnego wytwarzania pamięci niezwykle interesujące.

Obrazy te były nie tylko, jak ich brytyjskie odpowiedniki, performatywne w tym sensie, że wystawiały i wytwarzały określone rozumienie wojny, a przez medium wystawy i reprodukcji były w stanie powtarzać historię niezliczoną liczbę razy. Istota ich performatywności opierała się, paradoksalnie, właśnie na ich konserwatywnej i zapóźnionej, rodem z XIX wieku, formie. Jawiły się one bowiem jako repetycja, rodzaj malarskiego reperformansu polskiej historii poprzedniego stulecia z jej dramatycznymi punktami kulminacyjnymi: epopeją napoleońską ${ }^{14}$, nieudanymi powstaniami narodowymi i walkami narodowo-wyzwoleńczymi. Wystawienie historii narodowej, jakie się za ich pomocą odbywało, różniło się jednak zasadniczo od „oryginału”, gdyż za pomocą wbudowanej koncepcji narodzin przez śmierć, potwierdzonego dodatkowo irredentą państwa, do której doszło wraz z zakończeniem wojny, kończyło się ono nie kolejną katastrofą, sybirskimi etapami czy emigracją, lecz zwycięstwem i odrodzeniem. Powyższe znaczenia, co ważne, istnieją nie tylko w warstwie formalnej, w malaturze obrazów, lecz także w dyskursie wytworzonym w procesie ich instytucjonalizacji.

Z okazji wystawy sztuki legionowej w Krakowie Jerzy Remer pisał w następujący sposób:

W tworach artystycznych uobecnił się Duch Polski. [...] Boć sztuka, jaką tutaj w Pałacu oglądamy, nie tylko zbliżyła naszym oczom żołnierza polskiego i jego odrębny świat wojny [...]. I przez to $[\ldots]$ wystawa $[\ldots]$ ma tak doniosłe znaczenie dla społeczeństwa, z którego rekrutuje się żołnierz polski, że myśl i uczucie nasze uzbroiła w wiarę i entuzjazm, a dla potomnych pozostawiła zbożnymi rękoma rysowane i malowane certyfikaty i dokumenty, że Polska współczesna rycerską sprawą stoi i dopomina się na polach bitew o byt swój niezależny i nie ograniczony. Rozglądając się po dziełach sztuki, nabieramy czucia samych siebie i dotykamy się jak gdyby palcami momentu, w którym staje się Ona żywa, wolna (Remer 1916: 10-11).

Owo taktylne - „jak gdyby palcami” - doświadczenie i przeżywanie „malowanych certyfikatów" jest dobrym świadectwem ukazującym zarówno logikę zmartwychwstania, w której dialektyce obrazy-certyfikaty stają się unieważniającym akt zgonu odpisem aktu ponownego urodzenia, jak i performatywną ich siłę. W myśl tej samej logiki w katalogu lubelskiej wystawy legionowej pisał Józef Andrzej Teslar, demonstrując sposób na wystawianie historii z ubiegłych stuleci:

Stare orły napoleońskich Legionów przetarly oczy, ujrzawszy w kurzawie tylu bitew opromienione tego słońca blaskiem - śniade twarze szarych legionowych żołnierzy. Na odgłos strza-

14 Więcej na ten temat, zwłaszcza zaś o znaczeniu postaci księcia Józefa Poniatowskiego pisałem w: Szymański $2015 b$. 
łów spod Mołotkowa, Krzywopłotów i Lasków obudzili się polegli ongiś pod Racławicami, Raszynem, Grochowem i Ostrołęką. Tryumfalnemu okrzykowi Kozietulskiego z pod Samosierry odpowiedziało szalone „hurra!” szarżujących na poczwórne okopy moskiewskie ułanów szwadronu Wąsowicza pod Rokitną (Teslar 1917: 5).

Tego rodzaju reperformans wytwarzający konkretną pamięć i nakazujący przeżywanie wojny we właściwy sposób, był również wpisany w szereg służących sprawie legionowej wydawnictw kolportowanych podczas wojny. Możemy odczytywać je jako instrukcje do „obsługi wzroku” i napomnienie do właściwego zachowania; skrypt, który musiał automatycznie aktualizować się podczas odbioru obrazów. W wydawanej w Lublinie „Gazecie Ludowej” odnalazłem listę publikacji dostępnej w „Składnicy Wydawnictw Dep.[ozytury] Wojsk.[owej] w Piotrkowie" (Gazeta Ludowa: 16), gdzie swoją siedzibę miał Departament Wojskowy NKN-u. Wśród polecanych wydawnictw, będących „cennymi dokumentami »Wielkich Dni«” (ibid.), znalazły się, m.in., O żotnierzu polskim 1795-1915 Kazimierza Tetmajera oraz Ziemowita Buławy ${ }^{15}$ Piotrków na wiosnę 1915 roku.

Już tytuły obu książek wskazują na repetytywny charakter historii i performatywny potencjał jej powtórzenia. Książka Tetmajera sugeruje użytymi datami sensowne wypełnienie się czasu beznadziei (od trzeciego rozbioru do chwili obecnej, I wojny światowej „Wielkich Dni”) i ciągłość państwa w osobie żołnierza polskiego. Buława metaforyzuje zaś wiosnę, która dopełnia czas za sprawą cyklicznego i naturalnego odrodzenia przyrody. Takie odczytanie gruntuje się podczas lektury. Tetmajer używając - jakże scenicznej i performatywnej - metafory wżycia, a także aluzji do Akropolis Stanisława Wyspiańskiego, kieruje słowa do żołnierzy i pisze:

Naród polski ma także swoją Legendę: walkę o niepodległość. Wy jesteście nową opowieścią tej Legendy Polskiej. [...] Polacy dzisiejsi wżyli się w pieśń o dawnych bohaterach: szabla Kościuszki, Dąbrowskiego, Poniatowskiego, lance z chorągiewkami ułanów 31-go roku, dubeltówki, pałasze powstańców styczniowych, wypełniły im oczy. [...] Legenda odwróciła nową kartę. Lub może z dawnych kart Legendy Polskiej wyszły żywe figury? Teatr to Wyspiańskiego (Tetmajer 1915: 98).

Przeszłość zostaje reanimowana i wystawiona raz jeszcze także w dziełku Buławy:

Jeśli duchy przodków mają moc błądzenia po ziemiach, któremi za życia władały, to dnia pierwszego tegorocznej wiosny dźwignęly się pewnie z grobowisk Piotrkowa i pewnie długo w zachwycie i trwodze ważyly się jasne wśród słonecznej ciszy nad polskiej rzeszy tłumnym korowodem. [... ] Błogosławić duchy musiały / te polskich rycerzy drużyny, / co z odrętwiałej ziemi / głos życia swą stopą dobyły... (Buława 1915: 12).

Ta koherentna i performatywna pamięć wojny, została jednak okupiona, jak już wspomniałem, licznymi ofiarami. Możemy myśleć o nich jako o lukach w polskiej pamięci kulturowej, bowiem hegemoniczna pamięć wojny jest w istocie pamięcią Legionów. Wojna w takim ujęciu nie ma w sobie nic z traumatycznego, podkreślanego np. w Wielkiej Brytanii,

\footnotetext{
15 Ziemowit Buława to pseudonim działacza NKN-u, slawisty i legionisty prowadzącego z ramienia NKN-u misje dyplomatyczne na Bałkanach, Tadeusza Stanisława Grabowskiego.
} 
przeżycia; przeciwnie, jest afirmatywnie pomyślanym miejscem pamięci ściśle związanym z walką o niepodległość, z dominującą postacią Józefa Piłsudskiego i wydarzeniami dziejącymi się na froncie wschodnim. Przeżycie i światopogląd ok. 30000 żołnierzy, którzy przewinęli się przez Legiony, wyparły doświadczenia 3,3 miliona żołnierzy narodowości polskiej, walczących przeciwko sobie przez cztery lata wojny na frontach wschodnim, zachodnim i południowym (Kaczmarek 2014: 86) ${ }^{16}$. Wielokierunkowa w istocie polska pamięć wojny musiała oniemieć wobec - zrozumiałej skądinąd - wielkiej legionowej narracji niepodległościowej. Nie miała szans z uzbrojonymi w pióra, pędzle i dłuta, stacjonującymi w galeriach i składach księgarskich legionistami. Jak pisze Ryszard Kaczmarek, tym zapomnianym w kraju, skąd pochodzili, Polakom „z armii kajzera pozostała gorycz po przegranej w wojnie, która nie była ich wojną. Wiszące na ścianach domów [na Górnym Śląsku] wyblakłe zdjęcia żołnierzy w wyjściowych niebieskich mundurach stały się symbolami bezsensu wojny" (ibid.: 26).

\section{(2) Pamięć wojny po wielu innych wojnach. Wystawianie historii po stu latach}

Wydaje się, że tak jak sto lat temu, także dziś formy pamięci wypracowane przez sztukę w Wielkiej Brytanii z okazji obchodów stulecia Wielkiej Wojny stawiają w centrum problem właściwego jej przeżycia i pamiętania. Sto lat temu, jak usiłowałem to wykazać, performatywne znaczenie artefaktów zostało uruchomione za pomocą instytucjonalnych mechanizmów, które z jednej strony wystawiały (performowały) historię tak, jak rozumiał to Rokem, z drugiej zaś uczyły, czy wręcz narzucały, odpowiednie sposoby zachowania i pamiętania przez swych odbiorców, niejako ucieleśniając je w nich. Współczesne próby reanimacji pamięci za pomocą sztuki natomiast wprost odnoszą się do praktyk performatywnych, które w ostatnim półwieczu na stałe weszły do kanonu praktyki i teorii artystycznej. Można je zatem z łatwością odczytywać np. w kontekście takich, zasadniczych dla sztuki współczesnej, performatywnych teorii, jak estetyka relacyjna ${ }^{17}$ czy sztuka partycypacyjna, dla których właśnie czasowy aspekt dziania się i wytwarzania pewnych praktyk czy zachowań determinuje zwrot społeczny, jaki się za ich pomocą dokonuje. Na kilku przykładach postaram się teraz przybliżyć takie praktyki.

Dzięki uruchomionemu z okazji odbywających się w Wielkiej Brytanii w latach 20142018 obchodów stulecia wojny programowi 14-18 NOW został zrealizowany w przestrzeni publicznej szereg działań o charakterze artystycznym i komemoratywnym zarazem ${ }^{18}$. Jednym z zaproszonych artystów był Jeremy Deller, nagrodzony w 2004 roku prestiżową

\footnotetext{
16 Liczba podana przez Ryszarda Kaczmarka nie jest jedyną, jaka pojawia się w próbie zliczenia Polaków biorących udział w walkach. Na temat problemów i rozbieżności w interpretacji liczby polskich rekrutów na Wielką Wojną pisze obszerniej Marcin Jarząbek (2017: 32-35).

17 Wykład tej wpływowej przede wszystkim dla sztuki lat dziewięćdziesiątych XX wieku teorii, którą z powodzeniem można stosować do sztuki aktualnej, daje Nicolas Bourriaud (2012).

18 Poza Jeremym Dellerem, prace w przestrzeni publicznej wykonali także, m.in., Peter Blake, Tobias Rehberger, Carlos Cruz-Diez, Ciara Phillips i Ryoji Ikeda.
} 
Nagrodą Turnera, który zaproponował performatywne działanie pt. We're Here Because We're Here (2016), wystawione (by tak rzec) 1 lipca 2016 roku, w stulecie bitwy nad Sommą. Praca Dellera wydarzyła się jednocześnie w wielu brytyjskich miastach. Wydarzyła się także niespodziewanie; nie była anonsowana w mediach, nikt nie dostał zaproszenia na wydarzenie, przygotowania utrzymywano w tajemnicy. O konkretnej godzinie 1600 ochotników pojawiło się, m.in., na dworcach kolejowych, w centrach handlowych, parkach, na skrzyżowaniach ulic. Każdy z nich był ubrany w replikę brytyjskiego munduru wojskowego z czasów I wojny światowej i został zaopatrzony w dowód tożsamości w formie karty wizytowej. Wypisano na niej imię i nazwisko żołnierza, jego dane personalne - wiek, stopień oraz nazwę oddziału, w którym służył, jak również datę jego śmierci. Deller wybrał nazwiska żołnierzy, którzy zginęli nad Sommą 1 lipca 1916 roku, czyli pierwszego dnia bitwy. Na takich swego rodzaju nieśmiertelnikach znajdował się również poprzedzony hasztagiem napis wearehere. Napis i tytuł pracy to część refrenu popularnej pieśni Auld Lang Syne, śpiewanej także w okopach przed bitwą przez brytyjskich żołnierzy. Wydelegowani przez artystę aktorzy stali w milczeniu, jakby czekając, siedzieli, palili papierosy, jedli, biwakowali; inni przemieszczali się miejskimi autobusami, podróżując wraz z „żywymi”. Rozdawali też swoje „papiery-wizytówki”, od czasu do czasu śpiewając tylko We're Here Because We're Here.

Praca Dellera, którą można klasyfikować jako żywą instalację lub performans delegowany, czyli, słowami Claire Bishop, jako „działania powierzane nieprofesjonalistom, których zadaniem jest odegranie, najczęściej w ramach galerii lub wystawy, pewnego aspektu ich tożsamości” (Bishop 2015: 382), nie była pierwszym tego typu działaniem w karierze artysty. Deller bowiem, jak zwraca uwagę badaczka, jest autorem symbolicznej dla sztuki partycypacyjnej pracy, której sens polega właśnie na uczestnictwie i wytwarzaniu sytuacji spotkania, Bitwy o Orgreave (2001) (ibid.: 61). Ta najbardziej znana praca artysty to

performans odtwarzający [re-enacting] brutalne starcia górników z policją konną, jakie miały miejsce w 1984 roku. We wsi Orgreave w Yorkshire zmierzyło się ze sobą prawie 8 tysięcy policjantów z oddziałów prewencji i około 5 tysięcy strajkujących górników. Była to jedna z kilku ostrych konfrontacji, do których doprowadził atak rządu Margaret Thatcher na górnictwo (ibid.: 63).

W rekonstrukcji bitwy udział wzięli zaproszeni przez artystę walczący ze sobą ćwierć wieku wcześniej górnicy i policjanci, a także członkowie niezwykle popularnych od przełomu wieków grup rekonstrukcyjnych. Deller wyreżyserował bitwę, część ról robotników powierzając policjantom, policjantów zaś robotnikom (ibid.). Porównanie Bitwy o Orgreave z We'Are Here Because We'Are Here zachęca do zadania pytania o podobieństwa i różnice, jakie się między nimi ujawniają: co w każdym przypadku powtarza się, co zaś (nowego) w powtórzeniu tym wydarza? Zwłaszcza, że obie prace Dellera znajdują się

pomiędzy dwiema tendencjami, które zwyczajowo sytuuje się na przeciwnych biegunach spektrum politycznego: ekscentryczną i uprawianą w czasie wolnym aktywnością rekonstrukcyjną (w której ramach, pod postacią rozrywki grupowej, entuzjastycznie odtwarza się [re-enact] krwawe bitwy) i sztuką performansu (od początku zainteresowaną kwestią odgrywania [re-enactment]) (ibid.: 67). 
Przywołana przez Bishop strategia re-enactment ma, jak przekonuje Rebecca Schneider, zasadnicze znaczenie $\mathrm{w}$ dzisiejszym performatywnym wytwarzaniu pamięci. Amerykańska badaczka pisze:

„Reenactment” to termin, który wszedł na przełomie XX i XXI wieku do ogólnego obiegu w środowiskach artystycznym, teatralnym i związanym z performansem. Praktyka od-grywania i od-twarzania dawnego zdarzenia, dzieła sztuki lub działania wybuchła na gruncie sztuk performatywnych wraz z rozkwitem rekonstrukcji historycznych oraz „historii żywej” propagowanych w muzeach historycznych, parkach tematycznych i stowarzyszeniach. Na różne sposoby reenactment stał się popularną i praktykowalną częścią tego, co nazwane zostało dwudziestowiecznym uniwersyteckim „przemysłem pamięci” (Schneider 2011:2).

Obie prace Dellera świadomie i w wyrafinowany sposób rozgrywają sytuację zarysowaną przez Schneider, a wpisane w nie powtórzenie (bitwy w przypadku Bitwy o Orgreave oraz pieśni w przypadku We're Here Because We're Here) generują nowe znaczenia i sposoby pamiętania. Bitwa o Orgreave została wystawiona w tym samym miejscu, w którym odbyła się po raz pierwszy, a obok ochotników wzięli w niej także udział uczestnicy jej pierwowzoru. Powtórzenie bitwy zmieniło, jak zauważa Bishop (2015: 66), jej postrzeganie w brytyjskiej historii najnowszej. Za sprawą grup rekonstrukcyjnych, tradycyjnie związanych z wystawieniem historii dawnej, bezpiecznej, bo nieuwikłanej w politykę, i nieco patetycznej, wydarzenie z połowy lat osiemdziesiątych XX wieku zostało uhistorycznione i, dzięki temu, stało się godne pamiętania, a towarzysząca mu pierwotnie zła prasa została dyskursywnie zneutralizowana (ibid.). W przypadku realizacji Dellera z 2016 roku mamy zaś do czynienia z powtórzeniem tytułowego, jednego wersu pieśni wykonywanej przez żołnierzy pierwotnie w okopach nad Sommą. W przeciwieństwie do opartej na tożsamości miejsca i uczestników Bitwy o Orgreave, strukturę We're Here Because Wére Here zbudowano na freudowskiej koncepcji niesamowitości, która, jak wiadomo, polega na niepoprawnym w pewnym sensie i niecodziennym zestawieniu znajomych skądinąd elementów. I tak, wers pieśni zostaje wykonany nie w okopach nad Sommą, co byłoby adekwatne według logiki Bitwy o Orgreave, lecz w miejscach publicznych w całej Wielkiej Brytanii; kojarzone przez wszystkich Brytyjczyków z Wielką Wojną mundury opuściły przestrzenie muzealne, plany filmowe i sceny teatralne, gdzie dziś spodziewamy się je zobaczyć, trafiając do rzeczywistego tu i teraz. W końcu, rzecz zapewne kluczowa, performansu nie wykonują, co oczywiste, uczestnicy bitwy pod Sommą, lecz ochotnicy, którzy ucieleśniają historię sprzed stu lat, a „wżywając się”, jak powiedziałby Tetmajer (1915: 98), w ciała pochowanych na cmentarzach we Francji zmarłych, re-animują historię i pamięć.

Re-enactment żołnierskiej pieśni, tak jak został zaprojektowany przez Dellera, w istotny sposób zmienia jej pesymistyczne znaczenie, nadpisując nad brytyjską pamięcią Wielkiej Wojny nowe sensy. O ile wykonanie tautologicznego na swój sposób wersu „jesteśmy tu, bo jesteśmy tu" w okopach nad Sommą w 1916 roku ukazywało bezsens wydarzenia, w którym przyszło uczestniczyć żołnierzom rezygnującym niejako z innych prób zrozumienia swojego położenia ${ }^{19}$, o tyle współczesne wykonanie go w przestrzeni publicznej pozytywnie

\footnotetext{
19 O bezsensie wojny w pamięci brytyjskiej, właśnie w odniesieniu do bitwy nad Sommą pisał w swojej klasycznej pracy Paul Fussell (2013: 75-81).
} 
przewartościowuje jego pierwotny (bez)sens. Martwi żołnierze wracają z Francji do domu i będąc teraz tu, są w końcu tu.

Re-enactment Dellera nie jest jedynym działaniem performatywnym i partycypacyjnym, wykorzystującym artefakty, wydarzenia i działania związane z pamięcią I wojny światowej, a wytworzone w trakcie jej trwania lub bezpośrednio po niej. Dobrym przykładem ożywiania przeszłości i odnawiania pamięci o wojnie, jakie zachodzą w dzisiejszej Wielkiej Brytanii, jest zrealizowany także w ramach programu 14-18 NOW, rozpoczęty w 2014 roku projekt o charakterze time-specific pt. List do Nieznanego Żotnierza (Letter to an Unknown Soldier ${ }^{20}$. Projekt ten nie tylko re-animuje tytułowego Nieznanego Żołnierza, którego groby i pomniki powstawały po wojnie na całym świecie, sięga bowiem po konkretny pomnik Wielkiej Wojny - odsłonięty w 1922 roku na londyńskim dworcu kolejowym Paddington Great Western Railway War Memorial. Monumentalny, wykonany ze spiżu i kamienia, statuaryczny pomnik autorstwa rzeźbiarza Charlesa Sargeanta Jaggera i architekta Thomasa S. Taita, przedstawia zadumanego żołnierza w mundurze z okresu I wojny światowej, ze spuszczonym wzrokiem czytającego list, który zapewne otrzymał był z domu. To ten majestatyczny i staroświecki monument stał się obiektem performatywnych działań o charakterze re-enactmentu, dziejących się w ramach projektu List do Nieznanego Żotnierza.

Projekt polegał na zaproszeniu wszystkich chętnych do pisania listów do spiżowego żołnierza. Struktura powtórzenia była więc w tym przypadku, jak widać, bardziej złożona od tej wyznaczającej logikę pracy Dellera. Spiżowy bohater bowiem, jak i odlany w metalu list, który czyta, są przecież figurami symbolicznymi, a rzeźbiarz nie wymodelował tekstu listu, którego treści z powodu usytuowania figury i tak nie moglibyśmy przeczytać. Stojący za projektem re-enactment miał zatem charakter raczej fantazmatyczny, od-grywając i od-twarzając wydarzenie, do którego nigdy nie doszło; było to reperformowanie całej praktyki kulturowej pisania listów na front, charakterystycznej także dla Wielkiej Wojny. Stojący za projektem Neil Bartlett i Kate Pullinger tak pisali o wydarzeniu:

Istotne było dla nas stworzenie przestrzeni dla ludzi, by raz jeszcze przemyśleli znajomą przecież ikonografię związaną z pomnikami wojennymi: cenotafami, czerwonymi makami i milczeniem. Postawiliśmy im następujące pytania: gdybyście mogli, co powiedzielibyście o tej wojnie, uwzględniając to, co wiemy na jej temat po stu latach, i mając do dyspozycji wasze doświadczenie życia i śmierci, co byście powiedzieli? Gdybyście mogli wysłać osobisty list temu żołnierzowi, który służył i został zabity podczas I wojny światowej, co byście napisali? (Barlett and Pullinger).

Skala reakcji publiczności zdumiała organizatorów, którzy zgromadzili ponad 30000 listów napisanych do rzeźby. Wszystkie listy zostaną zarchiwizowane i trafią do zbiorów Biblioteki Brytyjskiej. W ten sposób performans zamieni się w materiał archiwalny, być może do czasu kolejnego wystawienia tej samej historii.

W porównaniu z brytyjskimi performatywnymi praktykami pamięci I wojny światowej wykorzystywanymi przez artystki i artystów współczesnych, polska wizualna postpamięć

20 Projekt rozpoczął się 28 czerwca 2014 roku, w stulecie zamachu w Sarajewie, i zakończył 4 sierpnia 2014 roku - równo sto lat po ogłoszeniu decyzji o przystąpieniu Wielkiej Brytanii do wojny. 
wojny właściwie nie istnieje ${ }^{21}$. Nie pojawiły się dotąd w sztuce współczesnej - być może zmieni się to w 2018 roku, kiedy będziemy świętować setną rocznicę zakończenia wojny i polską niepodległość - żadne dzieła poświęcone I wojnie i jej pamiętaniu ${ }^{22}$. Milczenie sztuki współczesnej, przy jednoczesnym ciągłym jej zainteresowaniu wydarzeniami związanymi z II wojną światową, wydaje się symptomatyczne. Potwierdza też tezę o niepamiętaniu Wielkiej Wojny dzisiaj i przesłonięciu jej znaczenia przez lata 1939-1945.

Owszem, w ostatnich latach odbyly się w Polsce specyficzne wystawienia historii o charakterze powtórzenia, otwarte jednak pozostaje pytanie, od którego rozpocząłem te refleksje, pytanie z zakresu etyki i estetyki zarazem: o stosowność i formę. Mam na myśli wszelkiego rodzaju rekonstrukcje bitew z okresu I wojny światowej staczanych raz jeszcze przez grupy rekonstrukcyjne w 2014 roku pod Łowczówkiem, Limanową, cyklicznie zaś pod Gorlicami. Rekonstrukcja tej ostatniej, zasadniczej dla frontu wschodniego bitwy, w której w imperialnych mundurach wzięli też udział Polacy, odbyła się ostatni raz 30 kwietnia 2017 roku w małopolskiej Sękowej. Plakat anonsujący wydarzenie zapowiadał koncert pieśni patriotycznych oraz degustację potraw kuchni wojskowej. Atrakcją miał być także dość to, trzeba przyznać, ironiczne w kontekście cyklicznego wystawiania historii - „jedyny i niepowtarzalny pokaz zwiadu lotniczego lotnictwa cesarskiego!"23. Naturalnie, rekonstrukcje bitew spełniają założenia re-enactmentu, są także, co istotne, performatywnymi, cielesnymi praktykami pamięci. Zasadna pozostaje jednocześnie wątpliwość, czy takie performanse pamięci wobec braku innych propozycji, jak te, które opisywałem na przykładach brytyjskich, są stosowną i właściwą formą pamiętania.

Podobny problem daje się zdiagnozować w przypadku wielu rocznicowych ekspozycji, jakie zostały zorganizowane w polskich instytucjach wystawienniczych. Nie opowiadają one w nowy sposób historii, a wystawiając ją ponownie za pomocą medium wystawy, zdają się powtarzać jedynie jej wersję. Nie przepisują polskiej pamięci I wojny światowej, dopowiadając historie stanowiące dotąd, jak je określiłem, luki w polskiej pamięci kulturowej; nie odnawiają znaczeń, zadowalając się, jak się wydaje, ich reprodukowaniem ${ }^{24}$. A to, jak

21 Ta sytuacja w polskim uniwersum kulturowym domaga się naturalnie szerszego, wykraczającego poza objętość tego tekstu, komentarza. Za najważniejsze przyczyny takiego stanu rzeczy należy uznać trzy: po pierwsze, skomplikowany stosunek do pamiętania I wojny światowej w II RP; po drugie, wstrząs II wojny światowej, która zajmuje znacznie bardziej eksponowane miejsce w polskiej pamięci niż jej poprzedniczka; po trzecie, politykę historyczną w latach 1945-1989, która ani nie podkreślała znaczenia I wojny światowej, ani nie eksponowała historii Legionów i postaci Józefa Piłsudskiego.

22 Poza filmem Karola Radziszewskiego MS 101 z moim scenariuszem, będącego biograficzną fantazją na temat Ludwiga Wittgensteina i Georga Trakla, którego akcja rozgrywa się w rzeczywistości wojennej 1914 roku, oraz prac Barbary Strykowskiej tematyzujących zburzenie Kalisza w 1914 roku i postać Marii Dąbrowskiej. Te prace pokazywałem jako kurator na wystawie artystki pt. Wojna powieczna i literatura w Galerii Sztuki im. Jana Tarasina w Kaliszu w 2016 roku. Pozostają one, póki co, wyjątkami potwierdzającymi regułę.

23 Za: http://www.gok.sekowa.pl/index.php/88-rekonstrukcja-bitwy-pod-gorlicami-sekowa-2017 [1.09.2017].

24 Najlepszym przykładem tego typu reprodukowania może być otwarta w 2016 roku w Muzeum Narodowym w Krakowie wystawa pt. Sztuka Legionów Polskich. Swoim tytułem i zawartością przywołuje omawianą w tym artykule, ważną wystawę przygotowaną przez Mycielskiego w 1916 roku. Wystawa jednak nie uwzględnia innego przecież niż sto lat temu i zmienionego przez kolejne wojny kontekstu, stając się raczej nie reenactmentem, a jego karykaturą. Interesujący w tym kontekście jest także fakt, że w tej samej przestrzeni, w której ją umieszczono, w latach 2014-2015 odbywała się otwarta w stulecie wymarszu I Kadrowej ekspozycja pt. Legiony Polskie 1914-1918. Sztuka Legionów Polskich pod patronatem Antoniego Macierewicza - zastąpiła wystawę pod patronatem Bronisława Komorowskiego, wykorzystując w większości te same obiekty i część aranżacji oraz stając się przez to raczej symulakralnym powtórzeniem powtórzenia, kopią bez oryginału niż deklarowanym przez MNK reenactmentem wystawy z 1916 roku. 
zauważa w swym klasycznym, poświęconym właśnie powtórzeniu, tekście Hal Foster, odwołując się do teorii Jacques’a Lacana, nie jest wystarczające:

Realne nie poddaje się przedstawieniu; można je tylko powtarzać, a wręcz trzeba. „Wiederholen nie oznacza Reproduzieren" [...] twierdzi Lacan, przywołując etymologiczne rozróżnienie, które wprowadził Freud, pisząc o powtórzeniu; powtórzenie to nie reprodukcja (Foster 2010: 160).

Dopowiadając tę myśl: właściwe - tzn. udane - powtórzenie nie może być tylko i wyłącznie reprodukcją starych znaków, które utraciły dawną moc znaczenia. Taka reprodukcja bowiem, czy też nieudolna kopia, nie przybliża nas nawet do postulowanego oryginalnego przeżycia. Dzisiejsze powtórzenie, aby działać, musi być bowiem oryginalniejsze od samego oryginału.

\section{Bibliografia}

Art from the First World War 2014. London: Imperial War Museum.

Barlett, Neil and Kate Pullinger. „Letter to an Unknown Soldier”. https://www.1418now.org.uk/letter/about/ [1.09.2017].

Bishop, Claire 2015. Sztuczne piekła. Sztuka partycypacyjna i polityka widowni. Tłumaczenie Jacek Staniszewski. Warszawa: Fundacja Nowej Kultury Bęc Zmiana.

Bourriaud, Nicolas 2012. Estetyka relacyjna. Tłumaczenie Łukasz Białkowski. Kraków: Muzeum Sztuki Współczesnej w Krakowie.

Buława, Ziemowit 1915. Piotrków na wiosnę 1915 roku. (Z notatek i wrażeń legionisty). Piotrków: Departament Wojskowy N.K.N.

Crane, David 2013. Empires of the Dead: How One Man's Vision Led to the Creation of WWI's War Graves. London: William Collins.

Drozdowski, Mateusz 2017. Naczelny Komitet Narodowy (1914-1918). Polityczne i organizacyjne zaplecze Legionów Polskich. Kraków: Towarzystwo Wydawnicze „Historia Iagellonica”.

Eksteins, Modris 2014. Święto wiosny. Wielka wojna i narodziny nowego wieku. Tłumaczenie Krystyna Rabińska. Poznań: Zysk i S-ka.

Foster, Hal 2010. Powrót Realnego. Awangarda u schyłku XX wieku. Tłumaczenie Mateusz Borowski, Małgorzata Sugiera. Kraków: Universitas.

Fussell, Paul 2013. The Great War and Modern Memory. Oxford: Oxford University Press.

Gazeta Ludowa 31.10.1915, nr 1.

Gough, Paul. „Why Paint War? British and Belgian Artists in World War One”. https://www.bl.uk/ world-war-one/articles/why-paint-war-british-and-belgian-artists [1.09.2017].

Janion, Maria 1998. Płacz generała. Eseje o wojnie. Warszawa: Wydawnictwo Sic!.

Jarząbek, Marcin 2017. Legioniści i inni. Pamięć zbiorowa weteranów I wojny światowej w Polsce i Czechostowacji okresu międzywojennego. Kraków: Universitas.

Kaczmarek, Ryszard 2014. Polacy $w$ armii kajzera na frontach pierwszej wojny światowej. Kraków: Wydawnictwo Literackie.

Macdonald, Sharon 2013. Memorylands: Heritage and Identity in Europe Today. London-New York: Routledge.

Malvern, Sue. „Art”. W: International Encyclopedia of the First World War. https://encyclopedia.19141918-online.net/article/art [1.09.2017]. 
Milewska, Wacława i Maria Zientara 1999. Sztuka Legionów Polskich i jej twórcy 1914-1918. Kraków: Fundacja Dokumentacji Czynu Niepodległościowego, Księgarnia Akademicka.

Nash, Paul 1949. Outline: An Autobiography and Other Writings. London: Faber \& Faber.

Nora, Pierre 1989. „Between Memory and History: les lieux de mémoire”. Representations 26: 7-25.

Remer, Jerzy 1916. Legiony w sztuce. Wystawa w Pałacu Sztuk Pięknych w Krakowie, 1916. Kraków: Centralne Biuro Wydawnictw N.K.N.

Rokem, Freddie 2010. Wystawianie historii. Teatralne obrazy przeszłości we wspótczesnym teatrze. Tłumaczenie Mateusz Borowski, Małgorzata Sugiera. Kraków: Księgarnia Akademicka.

Schneider, Rebecca 2011. Performing Remains: Art and War in Times of Theatrical Reenactment. London-New York: Routledge.

Stein, Gertruda 1974. Picasso. Tłumaczenie Mira Michałowska. Warszawa: Wydawnictwa Artystyczne i Filmowe.

Szymański, Wojciech 2015a. „Wieczny Grunwald albo ewiges Tannenberg. Historia historii (jako) pola bitwy”. W: Anna Markowska (red.). Przeszłość, która nie chce przeminać. Historia, pamięć, zapomnienie w pracach Doroty Nieznalskiej. Sopot: Państwowa Galeria Sztuki.

- 2015b. „Images from the Eastern Front. Great Returns or Death among Old Decorations? Remarks on Representation of the Great War in Polish Art”. W: Anna Branach-Kallas, Natalia Sabiniarz, Nelly Strehlau (red.). Conflicting Discourses, Competing Memories: Commemorating the First World War. Torun: Wydawnictwo Naukowe Uniwersytetu Mikołaja Kopernika.

Teslar, Józef 1917. „Wstęp”. W: Katalog Wystawy Legionów Polskich. Kraków: Komitet Wystawowy.

Tetmajer, Kazimierz 1915. O żotnierzu polskim 1795-1915. Oświęcim: Naczelny Komitet Narodowy.

Traba, Robert 2003. „Zapomniana wojna. Wydarzenia lat 1914-1918 w polskiej i niemieckiej pamięci zbiorowej”. W: Andreas Lawaty, Hubert Orłowski (red.). Polacy i Niemcy. Historia kultura - polityka. Poznań: Wydawnictwo Poznańskie.

White, Hayden 2009. „Zdarzenie modernistyczne”. Tłumaczenie Maciej Nowak. W: Idem. Proza historyczna. Ewa Domańska (red.). Kraków: Universitas.

Winter, Jay 2014. Sites of Memory, Sites of Mourning: The Great War in European Cultural History. Cambridge: Cambridge University Press. 